\title{
ANALISIS POLA KONSUMSI PANGAN RUMAH TANGGA (Studi Kasus di Desa Kandang Kecamatan Tabir Kabupaten Merangin)
}

\author{
Asnawati Is $^{\left.1^{*}\right)}$, Wahyu Triani ${ }^{1)}$, Isyaturriyadhah ${ }^{1)}$ \\ ${ }^{1}$ Program Studi Agribisnis, Fakultas Pertanian, Universitas Muara Bungo, Jl.Pendidikan, RT.10 RW.02 No.10 \\ Kelurahan Sungai Binjai Kecamatan Bathin III. Kabupaten Bungo, \\ Jambi 372238, Indonesia.
}

*Corresponding author: zahira_siregar@yahoo.co.id

To cite this article:

Is, A., Triani, W., \& Isyaturriyadhah, I. (2021). Analisis Pola Konsumsi Pangan Rumah Tangga (Studi Kasus di Desa Kandang Kecamatan Tabir Kabupaten Merangin). JIA (Jurnal IImiah Agribisnis) : Jurnal Agribisnis dan IImu Sosial Ekonomi Pertanian, 6(6), 201 - 209. doi:http://dx.doi.org/10.37149/jia.v6i6.22652

Received: December 24, 2021; Accepted: December 30, 2021; Published: December 31, 2021

\begin{abstract}
The study's goal was to evaluate food consumption trends based on quantity and quality and the factors that impact food consumption patterns. From March 10 to April 10, 2020, the research was conducted in Kandang Village, Tabir District, Merangin Regency, Jambi Province. The hamlet was purposefully chosen (purposive sample) because it has a somewhat vulnerable or priority food situation according to the 2019 Merangin Regency Food Security Service statistics. Lowest when compared to other villages or sub-districts in Tabir District. The data were examined using quantitative descriptive analysis and the Nutrition Adequacy Level (TKG) method, which included Energy Adequacy Levels (TKE) and Protein Adequacy Levels (TKP), to establish household food consumption patterns based on quantity. The Expected Food Pattern Analysis (PPH) purpose was to evaluate food consumption patterns based on quality factors. Meanwhile, multiple linear regression analysis was utilized to investigate the elements that impact food intake patterns. The quantity-based study of food intake findings demonstrates that the deficit category still dominates the household's Energy Adequacy Level (TKE), with an average consumption of 1000 to $1300 \mathrm{kcal} / \mathrm{cap} /$ day compared to the required nutritional adequacy rate of $2150 \mathrm{kcal} / \mathrm{cap} . / \mathrm{hr}$. Meanwhile, the deficit group dominates the Protein Adequacy Level (TKP), accounting for $70 \%$ of the total with an average consumption of 19 to $38 \mathrm{~g} / \mathrm{cap} /$ day of the necessary nutritional adequacy rate of $57 \mathrm{~g} / \mathrm{cap} /$ day. After that, a PPH score of 83.2 was attained for the quality aspect, which was still below the optimum PPH score of 100 . Furthermore, the factors that influence household food consumption patterns, as shown by the $\mathrm{F}$ test with a significant value of 0.016 and the t-test with a substantial weight of 0.001 , include the number of family members.
\end{abstract}

Keywords: consumption pattern; PPH; TKE; TKG; TKP

\section{PENDAHULUAN}

Pangan merupakan kebutuhan manusia yang paling mendasar, dan merupakan salah satu hak asasi manusia yang dilindungi dalam Undang-Undang Dasar Negara Republik Indonesia Tahun 1945. Pada tahun 2017, biji-bijian dimakan 303,6 gram per kapita per hari, 56 umbi-umbian dikonsumsi 3 gram per kapita per hari, makanan hewani dikonsumsi 121,3 gram per kapita per hari, minyak dan lemak dikonsumsi 28,3 gram per kapita per hari, dan buah-buahan berminyak. /biji-bijian dikonsumsi 28,3 gram per kapita per hari. Gula 28,2 gram per kapita per hari, sayur dan buah 224,8 gram per kapita per hari, 6,5 gram per kapita per hari, 25 butir kacang, 7 gram per kapita per hari, 6,5 gram per kapita per hari, 25 butir per kapita per hari, 7 gram per kapita per hari hari, gula 28,2 gram per kapita per hari, sayur dan buah 224,8 gram per kapita per hari (Badan Ketahanan Pangan Kementerian Pertanian, 2018). Konsumsi pangan Indonesia masih didominasi oleh asupan karbohidrat tinggi yaitu dari kategori padi-padian, sebagai makanan pokok, dibandingkan dengan konsumsi protein, sayur, dan buah. Oleh karena itu, perubahan pola konsumsi pangan, serta 
peningkatan pendidikan dan kesadaran gizi masyarakat menjadi salah satu hal yang harus dilakukan untuk mendukung kualitas sumber daya manusia.

Perkiraan konsumsi pangan nasional didasarkan pada parameter kuantitatif dan kualitatif, seperti perkiraan asupan kalori dan protein berdasarkan angka kecukupan gizi yang disarankan penduduk Indonesia. Di Indonesia, AKG ditetapkan oleh Forum Penelitian Pangan dan Gizi Nasional (WNPG) yang telah ada sejak tahun 1978.. Menurut (Peraturan Menteri Kesehatan Republik Indonesia Nomor 75 Tahun 2013); (Badan Ketahanan Pangan Kementerian Pertanian, 2015), hasil AKG WNPG 2012 dengan pedoman kalori $2.150 \mathrm{kkal}$ dan 57 gram protein saat melakukan analisis konsumsi menggunakan teknik tersebut, semuanya dapat digunakan untuk menganalisis konsumsi pangan penduduk ditinjau dari kuantitasnya karena menurut Aemana et al. (2019) jika dibandingkan konsumsi pangan dengan konsumsi non pangan maka alokasi pengeluaran rumah tangga masih dialokasikan untuk konsumsi pangan.

Menurut BPS, (2020) Analisis Pola Pangan yang Diharapkan (PPH) digunakan untuk mengevaluasi ketersediaan pangan, konsumsi pangan (kuantitas dan komposisi/keanekaragaman), dan sebagai sumber perencanaan ketersediaan dan konsumsi pangan. Pola Pangan Harapkan (PPH) merupakan salah satu indikator yang digunakan untuk mengukur kualitas konsumsi pangan dan pengaturan pola makan berdasarkan persentase keseimbangan energi dari berbagai kategori makanan untuk memenuhi kebutuhan gizi baik kuantitas maupun kualitas. (1) biji-bijian, (2) umbiumbian, (3) makanan hewani, (4) minyak dan lemak, (5) buah-buahan/biji-bijian yang berminyak, (6) kacang-kacangan, (7) gula, (8) sayur-sayuran dan buah-buahan, dan (9) makanan lain termasuk dalam kategori makanan (Badan Ketahanan Pangan Kementerian Pertanian, 2018). Menurut Ansori, (2021) Konsumsi makanan umumnya tinggi untuk padi-padian, serta minyak dan lemak, sementara itu, konsumsi pangan per kapita penduduk untuk umbi-umbian, pangan hewani, dan pangan kelompok, seperti buah/biji-bijian berminyak, kacang-kacangan, gula, sayur, dan buah masih kurang.

Menurut Argandi et al., (2019) PPH berkorelasi positif dengan ukuran keluarga, tingkat pendidikan, dan tingkat pendapatan, menunjukkan bahwa semakin besar keluarga, semakin tinggi tingkat pendidikan, dan semakin tinggi tingkat pendapatan, semakin tinggi PPH. PPH di Kabupaten Merangin belum mencapai tingkat optimal pada tahun 2017, turun 92,5 poin dari nilai maksimal 100 . Hal ini bahwa ketersediaan pangan di Kabupaten Merangin belum mencapai tingkat yang diinginkan; ketersediaan pangan di Kabupaten sangat berbeda dengan di kecamatan bahkan desa. Penulis tertarik dengan pola konsumsi pangan di Merangin salah satunya Kecamatan Tabir, mengingat masih ada satu desa di Kecamatan Tabir yang masih mengalami kerawanan pangan yaitu di Desa Kandang memiliki peringkat kerawanan pangan prioritas tiga, menunjukkan bahwa merupakan desa yang sangat rawan pangan atau memiliki prioritas pangan terendah di Kecamatan Tabir. Tujuan penelitian ini untuk menganalisis pola konsumsi pangan rumah tangga.

\section{MATERI DAN METODE}

Penelitian ini dilaksanakan pada 10 Maret 2020 sampai dengan 10 April 2020 di Desa Kandang, Kecamatan Tabir, Kabupaten Merangin, Provinsi Jambi. Penentuan daerah penelitian dilakukan secara purposive. Daerah ini diangkat menjadi daerah penelitian karena menurut data Kabupaten Marangin, Desa Kandang merupakan Desa dengan kondisi pangan yang cukup rentan atau desa dengan prioritas pangan terendah jika di bandingkan dengan Desa atau Kelurahan lain di Kecamatan Tabir yang sudah mencapai kondisi tahan pangan. Jenis makanan yang dikonsumsi oleh keluarga menggunakan teknik food recall 24 jam yang lalu merupakan data primer yang akan dikumpulkan. Menurut Supariasa (2013), Jika hanya bertujuan untuk mengetahui jumlah rata-rata konsumsi sekelompok responden, maka Food Recall $1 \times 24$ jam atau penimbangan satu hari sudah cukup", dan jika hanya bertujuan untuk menentukan rata-rata jumlah konsumsi sekelompok responden, maka Food Recall 1 × 24 jam atau penimbangan satu hari sudah cukup. Dalam penelitian ini, analisis deskriptif kuantitatif dipadukan dengan penelitian survei untuk mengidentifikasi pola konsumsi pangan masyarakat di Kecamatan Tabir, Kabupaten Merangin, Provinsi Jambi. Metode yang digunakan untuk memilih responden dalam penelitian ini adalah random sampling (Sugiyono, 2015). Penduduk Desa Kandang yang berpenduduk 424 KK menjadi subjek penelitian ini. Dalam penelitian ini peneliti mengambil sampel 15\% dari seluruh populasi, sehingga diperoleh sampel 64 keluarga. Hasil dari kuesioner dihitung dan diklasifikasikan ke dalam sembilan kelompok makanan (padi-padian, umbi-umbian, gula, buah/biji-bijian berminyak, minyak dan lemak, makanan hewani, kacang-kacangan, sayuran dan buah) untuk mencapai tujuan penelitian. Hasil pengelompokan tersebut kemudian diperiksa dengan menggunakan metode sebagai berikut: 
1. Analisis pola konsumsi berdasarkan aspek Kuantitas

Angka Kecukupan Energi (AKE) dan Angka Kecukupan Protein (AKP) digunakan untuk menghitung Angka Kecukupan Gizi (AKG). Analisis gizi dapat dilakukan baik secara otomatis atau manual, memanfaatkan DKBM untuk menghitung kandungan gizi makanan tertentu.

Untuk mengetahui Konsumsi aktual keluarga, dapat dihitung dengan cara:

Konsumsi Aktual = Konsumsi Pangan Rumah Tangga / Jumlah Keluarga

Berikut ini adalah rumus untuk menghitung zat gizi dalam bahan makanan:

$$
\mathrm{G}(\mathrm{e} / \mathrm{p})=\frac{A}{B d d} \times C
$$

Dimana: $\mathrm{G}(\mathrm{e} / \mathrm{p})=$ Energi atau protein yang dikonsumsi sebagai hasil dari makan, $\mathrm{A}=$ Jumlah bahan makanan $A=(\mathrm{gram})$, Porsi komponen makanan yang dapat dimakan, $0(\mathrm{Bdd})=$ Bagian yang dapat dimakan dari bahan makanan, $\mathrm{C}=$ Jumlah nutrisi dalam 100 gram bahan baku.

Jumlah makanan yang dikonsumsi ditinjau dari zat gizi yang termasuk dalam komponen makanan. Rumus di atas digunakan untuk mengetahui kecukupan asupan gizi suatu rumah tangga (AKG). Jumlah makanan yang dikonsumsi diukur dengan menggunakan parameter Tingkat Kecukupan Gizi (TKG), yaitu Tingkat Konsumsi Energi/TKE dan Tingkat Konsumsi Protein/TKP.

$$
\mathrm{TK}=\frac{K}{K C} \times 100 \%
$$

Dimana: TK = Tingkat Kecukupan (Energi/Protein) (persen), $\mathrm{K}=$ Jumlah Asupan Nutrisi (Energi/Protein), KC = Kecukupan nutrisi yang direkomendasikan" (energi/protein).

Rata-rata konsumsi energi dan protein akan dihitung dengan menggunakan hasil analisis bahan makanan selama satu hari, kemudian dibandingkan dengan tingkat kecukupan energi dan protein yang dibutuhkan. Menurut (Supariasa et al., 2002) tingkat energi dan protein dapat dikategorikan menggunakan pedoman yaitu TKG $\geq 100 \%$ AKG : Baik, TKG $80-99 \%$ AKG : Sedang, TKG $70-79 \%$ $A K G$ : Kurang, TKG $<70 \%$ AKG : Defisit

\section{Analisis pola konsumsi berdasarkan aspek Kualitas}

Data tersebut selanjutnya dianalisis dengan menggunakan metode Predicted Food Pattern Score (PPH) untuk memperkirakan pola konsumsi pangan berdasarkan faktor kualitas. Langkahlangkah menghitung PPH yaitu klasifikasi makanan, konversi jenis dan satuan, menentukan ketersediaan/konsumsi energi menurut kategori makanan, tentukan kandungan energi keseluruhan dari semua kategori makanan, tentukan berapa banyak energi yang disumbangkan setiap kelompok makanan terhadap energi keseluruhan yang dikonsumsi (persen), menghitung kontribusi energi masing-masing kelompok makanan terhadap angka kecukupan energi (persen AKE), tentukan skor akhir, menentukan skor AKE, perhitungan skor $\mathrm{PPH}$, menghitung skor total pola makanan yang diharapkan. skor pola harapan nasional memiliki skor optimal 100 menurut (Badan Ketahanan Pangan Kementerian Pertanian, 2018) dengan kriteria ideal $\geq 100$ dan belum ideal $<100$

\section{Kebiasaan makan dipengaruhi oleh berbagai faktor.}

Selanjutnya dengan menggunakan analisis linier berganda, ditemukan unsur-unsur yang mempengaruhi pola konsumsi pangan sebagai berikut:

$$
Y=a+b_{1} X_{1}+b_{2} X_{2}+b_{3} X_{3}+X_{4}+e
$$

Dimana: Y: Pola Konsumsi Pangan Rumah Tangga (gr/kapitaita/hari), a: Intersep konstan, $b_{1}$ : Estimasi koefisien parameter $(i=1,2,3, \ldots . . n), X_{1}$ : Tingkat pendidikan ibu rumah tangga (Tahun), $X_{2}$ : Pendapatan Keluarga (Rp/bulan), $\mathrm{X}_{3}$ : Jumlah anggota keluarga (jiwa), $\mathrm{X}_{4}$ : Usia Ibu Rumah Tangga (Tahun), e: Kesalahan 


\section{HASIL DAN PEMBAHASAN}

\section{Pola Konsumsi Pangan Berdasarkan Kuantitas}

Menilai jumlah makanan yang dikonsumsi, dapat digunakan Angka Kecukupan Gizi yang didasarkan pada volume makanan yang dikonsumsi dan konsumsi zat gizi yang termasuk dalam komponen makanan. Untuk mengukur tingkat kecukupan gizi dalam rumah tangga, penelitian ini melihat dua zat gizi yaitu energi dan protein. Ada dua kriteria yang digunakan untuk menilai berapa banyak makanan yang dikonsumsi individu: tingkat kecukupan energi (TKE) dan tingkat kecukupan protein (TKP).

Tabel 1. Tingkat kecukupan energi rumah tangga di Desa Kandang

\begin{tabular}{cccc}
\hline No & Kategori Tingkat Kecukupan Energi & Jumlah & Presentase $(\%)$ \\
\hline 1 & Baik & 13 & 20 \\
2 & Sedang & 11 & 17 \\
3 & Kurang & 18 & 28 \\
4 & Defisit & 22 & 34 \\
\hline & Jumlah & 64 & 100 \\
\hline
\end{tabular}

Sumber: Data primer, 2020

Dapat disimpulkan bahwa untuk rumah tangga sampel pada Desa Kandang mayoritas rumah tangganya untuk kategori Tingkat Kecukupan Gizi Energinya atau TKE masih di dominasi kategori Defisit, atau tingkat kecukupan energinya sangat rendah dari yang dianjurkan yakni $2150 \mathrm{kkal}$ per kapita perhari. Sebab dari rendahnya konsumsi energi pada Desa Kandang sehingga masih dominan Defisit adalah adanya beberapa kelompok pangan yang berdasarkan penelitian sangat jarang dikonsumsi sehingga hasil perhitungan energinya rendah oleh masyarakat Desa Kandang, yakni dapat dilihat pada tabel berikut:

Tabel 2. Konsumsi rata-rata energi kelompok pangan

\begin{tabular}{|c|c|c|}
\hline No & Kelompok Pangan & Konsumsi Rata-rata Energi kkal/kapita/hr \\
\hline 1 & Padi & 936.38 \\
\hline 2 & Umbi & 24.93 \\
\hline 3 & Hewani & 224.26 \\
\hline 4 & Minyak-Lemak & 255.62 \\
\hline 5 & Buah-Biji Berminyak & 46.88 \\
\hline 6 & Kacangan & 20.79 \\
\hline 7 & Gula & 87.96 \\
\hline 8 & Sayur/Buah & 166.49 \\
\hline 9 & Lainnya & 27.08 \\
\hline & Total & 1790.39 \\
\hline
\end{tabular}

Sumber: Data primer, 2020

Pada Tabel 2 total energi rata-rata adalah 1790,39 kkal/kapita/hr masih dibawah energi yang di anjurkan sebesar $2150 \mathrm{kkal} / \mathrm{kapita} / \mathrm{hr}$, hal itu karena kelompok pangan yang paling sedikit adalah pada umbi-umbian yang menunjukkan konsumsi energi $24,93 \mathrm{kkal} / \mathrm{kapita} / \mathrm{hr}$ dan kacang-kacangan dengan konsumsi energi 20,79 kkal/kapita/hr, rendahnya konsumsi pangan hasil energi pada kedua kelompok pangan tersebut dilihat dari jenis makanan yang dikonsumsi masyarakat.

Hal ini juga terbukti bahwa dari hasil olah data kuisioner 64 responden penelitian ada 8 responden yang mengkonsumsi kelompok pangan ubi jalar, ubi kayu/singkong dan kentang, kemudian dari konsumsi energi terendah kacang-kacangan ada 18 dari total 64 responden yang mengkonsumsi kacang-kacangan seperti tahu, tempe dan tauge. Rendahnya rumah tanggga yang mengkonsumsi kelompok pangan ini karena dari lampiran 7 rumah tangga banyak mengkonsumsi jenis kelompok pangan yang mengandung energi pada kelompok padi-padian, artinya konsep kenyang lebih disukai oleh penduduk setempat, yang tidak peduli dengan kandungan nutrisinya. Hamid et al. (2013) menyatakan keluarga akan memprioritaskan makanan murah atau makanan pokok seperti sumber energi pada tingkat pendapatan tertentu, tetapi seiring dengan meningkatnya pendapatan, konsumsi akan bergeser dari makanan murah ke makanan mahal seperti sumber protein. Derajat kecukupan gizi protein dalam keluarga merupakan kategori selanjutnya dalam aspek evaluasi kuantitas makanan, seperti terlihat pada tabel di bawah ini: 
Tabel 3. Tingkat kecukupan protein pada rumah tangga di Desa Kandang

\begin{tabular}{cccc}
\hline No & Kategori & Jumlah & Presentase (\%) \\
\hline 1 & Baik & 20 & 31 \\
2 & Sedang & 5 & 8 \\
3 & Kurang & 3 & 5 \\
4 & Defisit & 36 & 56 \\
\hline & Jumlah & 64 & 100 \\
\hline
\end{tabular}

Sumber: Data primer, 2020

Disimpulkan bahwa untuk rumah tangga sampel pada Desa Kandang mayoritas rumah tangganya untuk kategori tingkat kecukupan gizi proteinnya masih di dominasi kategori Defisit atau tingkat kecukupan proteinnya sangat rendah dari yang dianjurkan yakni 57 gram per kapita perhari. Masih banyaknya rumah tangga dalam kategori Defisit di Desa Kandang juga disebabkan masih adanya kelompok pangan yang memiliki kandungan banyak protein namun masih minim di konsumsi.

Tabel 4. Konsumsi Rata-rata Protein Kelompok Pangan

\begin{tabular}{clc}
\hline No & Kelompok Pangan & Konsumsi Rata-rata Protein gram/kapita/hr \\
\hline 1 & Padi & 17.77 \\
2 & Umbi & 0.30 \\
3 & Hewani & 20.05 \\
4 & Minyak-Lemak & 0 \\
5 & Buah-Biji Berminyak & 0.61 \\
6 & Kacangan & 2.14 \\
7 & Gula & 0 \\
8 & Sayur/Buah & 8.23 \\
9 & Lainnya & 1.19 \\
\hline & Total & 50,28 \\
\hline
\end{tabular}

Sumber: Data primer diolah, 2020

Konsumsi rata-rata protein pada Tabel 4 adalah 50,28 gr/kapita/hr, jumlah tersebut tentu masih dibawah anjuran sebesar $57 \mathrm{gr} / \mathrm{kapita} / \mathrm{hr}$. Kelompok pangan dengan yang tidak memiliki kandungan protein adalah gula dan minyak goreng, dalam hal ini kategori protein defisit dapat diakibatkan pada kelompok pangan umbi-umbian dengan protein total 0,30 dan buah/biji berminyak dengan rata-rata protein yang dikonsumsi adalah 0,61. Masyarakat Desa Kandang cenderung mengkonsumsi bahan pangan protein pada kelompok pangan bersumber dari hewani dan padipadian. Untuk pangan bersumber dari hewani, berdasarkan hasil kuisioner banyak masayarakat yang mengkonsumsi jenis ikan kering seperti teri dalam kesehariannya dan beberapa mengkonsumsi telur, ikan dan daging ayam. Sementara untuk kelompok padi-padian masyarakat cenderung mengkonsumsi beras sebagai sumber proteinnya.

Sama seperti TKE sebelumnya banyak mengkonsumsi jenis kelompok pangan yang mengandung protein masih pada kelompok padi-padian dan hewani meskipun kelompok hewani dikonsumsi pada hari-hari tertentu, artinya Konsep kenyang lebih disukai oleh penduduk setempat, yang tidak peduli dengan kandungan nutrisinya. Lebih lanjut Hamid et al. (2013) menyatakan keluarga akan memprioritaskan makanan murah atau makanan pokok seperti sumber energi pada tingkat pendapatan tertentu, tetapi seiring dengan meningkatnya pendapatan, konsumsi akan bergeser dari makanan murah ke makanan mahal seperti sumber protein. Dari hasil penelitian untuk penilaian aspek kuantitas pangan baik dari tingkat kecukupan energi maupun tingkat kecukupan protein, keduanya masih didominasi oleh kategori Defisit yang artinya sebagai suatu keadaan dimana asupan nutrisi tidak dapat memenuhi atau mencukupi kebutuhan metabolik tubuh (Nurafif et al., 2015). Meskipun pada kategori energi padi-padian menjadi penyumbang terbesar, namun pada protein, padi-padian di posisi kedua, hal demikian karena kandungan protein banyak terdapat di hewani. Dan diposisi pertama pada kategori protein adalah hewani meskipun dari total banyak konsumsinya padi-padian, sayur dan buah merupakan yang paling banyak di konsumsi.

\section{Pola Konsumsi Pangan Berdasarkan Aspek Kualitas}

Komposisi jenis dan jumlah rata-rata makanan yang dikonsumsi per orang setiap hari disebut pola konsumsi makanan. Pola konsumsi mengungkapkan sejauh mana keragaman pangan antar keluarga di wilayah penelitian, yang meliputi Desa Kandang, Kecamatan Tabir, Kabupaten Merangin. 
Tabel 5. Pola Pangan Harapan rumah tangga di Desa Kandang, Kecamatan Tabir, Kabupaten Merangin

\begin{tabular}{clcrrrrrr}
\hline No & \multicolumn{1}{c}{ Uraian } & $\begin{array}{c}\text { Konsumsi } \\
\text { (gr/kapita/hr) }\end{array}$ & $\begin{array}{c}\text { Energi } \\
\text { (kkal) }\end{array}$ & \multicolumn{1}{c}{$\begin{array}{c}\text { AKE } \\
\text { Ak }\end{array}$} & Bobot & $\begin{array}{c}\text { Skor } \\
\text { AKE }\end{array}$ & $\begin{array}{c}\text { Skor PPH } \\
\text { Ideal }\end{array}$ & $\begin{array}{r}\text { Skor } \\
\text { PPH }\end{array}$ \\
\hline 1 & Padi & 262.43 & 936.38 & 43.55 & 0.5 & 21.78 & 25 & 21.78 \\
2 & Umbi & 16.79 & 24.93 & 1.16 & 0.5 & 0.58 & 2.5 & 0.58 \\
3 & Hewani & 100.19 & 224.26 & 10.43 & 2 & 20.86 & 24 & 20.86 \\
4 & Minyak-Lemak & 28.46 & 255.62 & 11.89 & 0.5 & 5.94 & 5 & 5 \\
5 & Buah-Biji Berminyak & 38.43 & 46.88 & 2.18 & 0.5 & 1.09 & 1 & 1 \\
6 & Kacangan & 21.42 & 20.79 & 0.97 & 2 & 1.93 & 10 & 1.93 \\
7 & Gula & 24.26 & 87.96 & 4.09 & 0.5 & 2.05 & 2.5 & 2.05 \\
8 & Sayur/Buah & 236.54 & 166.49 & 7.74 & 5 & 38.72 & 30 & 30 \\
9 & Lainnya & 28.03 & 27.08 & 1.26 & 0 & 0.00 & 0 & 0 \\
\hline \multicolumn{2}{c}{ Total } & 756.55 & 1790.39 & 83.27 & 11.5 & 92.95 & 100 & 83.2 \\
\hline
\end{tabular}

Sumber: Data primer diolah, 2020

Pada Tabel 5 PPH dilokais penelitian adalah sebesar 83,2. Hal ini berarti Pola Pangan Harapan di Desa Kandang belum mencapai target ideal Nasioanl yakni dengan skor PPH 100 sesuai dengan anjuran Widiyakarya Nasional 2013 dan Badan Ketahanan Pangan 2015. Skor PPH di Desa Kandang juga masih dibawah skor PPH pada tingkat Kabupaten Merangin pada tahun 2017 yakni sebesar 92,5. Pada skor PPH kelompok pangan yang dikonsumsi tertinggi ada pada sayur dan buah yakni 30 dengan konsumsi rata-rata $236.54 \mathrm{gr} / \mathrm{kapita} / \mathrm{hr}$. Banyaknya konsumsi kelompok pangan sayur dan buah oleh masyarakat Desa Kandang dapat dipengaruhi oleh faktor ekonomi yang mempertimbangkan karena sayur mudah didapat dengan harga yang terjangkau dipasar jika dibandingkan dengan harga pangan lain seperti pangan hewani, namun demikian hal itu juga dapat dipengaruhi oleh selera masyarakat, karena selain sayur masih ada harga kelompok pangan lain yang lebih murah misal seperti olahan kedelai tempe dan tahu, namun masyarakat lebih dominan untuk memilih sayur sebagai makanan kesehariannya dibandingkan dengan kelompok pangan lain.

\section{Faktor-faktor yang Mempengaruhi Pola Konsumsi Pangan Rumah Tangga}

Variabel terikat dalam penelitian ini adalah konsumsi makanan gram per kapita per hari $(\mathrm{Y})$. Unsur internal dalam rumah digunakan sebagai faktor independen $(X)$ dalam penelitian ini, meliputi pendidikan IRT $\left(X_{1}\right)$, pendapatan $\left(X_{2}\right)$, jumlah anggota keluarga $\left(X_{3}\right)$, dan usia IRT $\left(X_{4}\right)$.

Tabel 6. Hasil Analisis Regresi

\begin{tabular}{lcrc}
\hline \multicolumn{1}{c}{ Variabel } & Koefisien Regresi & t-hitung & Signifikan \\
\hline Kostanta & 1098.109 & 3.675 & .001 \\
Pendidikan IRT $\left(\mathrm{X}_{1}\right)$ & -13.502 & -.963 & .340 \\
Pendapatan $\left(\mathrm{X}_{2}\right)$ & $3.849 \mathrm{E}-5$ & 1.089 & .281 \\
Jumlah Anggota Keluarga $\left(\mathrm{X}_{3}\right)$ & -142.236 & -3.544 & .001 \\
Usia IRT $\left(\mathrm{X}_{4}\right)$ & 7.017 & 1.339 & .186 \\
\hline R Square $\left(\mathrm{R}^{2)}\right.$ & 0.184 & & \\
Uji F & 3.336 & & .016 \\
Sig. & & & \\
\hline
\end{tabular}

Sumber: Data primer diolah, 2020

Model persamaan berikut dapat diturunkan dari uji regresi linier berganda pada Tabel 6: $Y=1098,109-13,502$ X1 + 0,00003849 X2 $-142,236$ X3 + 7,017 X4 Dari persamaan di atas dapat ditunjukkan bahwa:

1. Koefisien regresi $X_{1}$ sebesar -13.502 , artinya untuk setiap kenaikan pendidikan, konsumsi pangan rumah tangga turun sebesar $13.502 \mathrm{~g} / \mathrm{kapita} / \mathrm{hari}$.

2. Koefisien regresi $X_{2}$ adalah $0,3849 \times 10^{-4}$ yang berarti bahwa untuk setiap kenaikan pendapatan 10.000 rupiah, asupan makanan rumah tangga meningkat sebesar $0,3849 \mathrm{gr} / \mathrm{kapita} / \mathrm{hari}$.

3. Koefisien regresi $X_{3}$ adalah -142.236 , berarti untuk setiap penambahan anggota keluarga, asupan makanan rumah tangga berkurang sebesar $142.236 \mathrm{~g} / \mathrm{kapita} / \mathrm{hari}$.

4. Koefisien regresi $X_{4}$ sebesar 7,017 yang berarti bahwa setiap tahun ibu rumah tangga bertambah tua maka konsumsi pangan rumah tangganya meningkat sebesar 7,017 g/kapita/hari.

Tabel 6 menunjukkan bahwa koefisien determinasi, atau $R^{2}$ ( $R$ Square), untuk hasil regresi adalah 0,184 yaitu variabel bebas dapat menjelaskan 18,4 persen variabel terikat, sedangkan 81,6 
persen dijelaskan oleh variabel bebas yang tidak dimasukkan dalam penelitian. Karena nilai $R$ Square kurang dari $5 \%$ atau mendekati 0 , dapat dikatakan bahwa kapasitas variabel untuk menjelaskan variabel $\mathrm{Y}$ relatif terbatas. Hasil Uji F diperoleh nilai F-hitung sebesar 3,336 lebih besar dari F-tabel yaitu sebesar 2,53 dengan nilai signifikansi 0,016 yang menunjukkan bahwa nilai signifikansi tersebut lebih kecil dari 0,05 sesuai dengan hasil penelitian regresi linier berganda. Akibatnya $\mathrm{HO}$ ditolak dan Ha disetujui yang menunjukkan bahwa pendidikan IRT, pendapatan, jumlah anggota keluarga, dan usia berpengaruh besar terhadap kebiasaan konsumsi makanan secara bersamaan atau bersamaan. Hasil Uji t dibandingkan antara t-hitung dan t-tabel untuk melihat bagaimana masing-masing variabel mempengaruhi hasil.

\section{Pendidikan Ibu Rumah Tangga (X1)}

Nilai t-hitung sebesar $-0,963$ lebih kecil dari nilai t-tabel sebesar 1,671 dengan nilai signifikan 0,340 lebih besar dari 0,05 , menurut hasil pengujian. Akibatnya, $\mathrm{HO}$ diterima tetapi Ha ditolak. Hal ini menunjukkan bahwa pendidikan ibu rumah tangga memiliki dampak kecil pada tren konsumsi makanan rumah tangga. Koefisien regresi X1 bernilai negatif dengan nilai -13.502. Artinya untuk setiap tahun peningkatan pendidikan, konsumsi pangan rumah tangga mengalami penurunan sebesar 13,502 g/kapita/hari. Menurut Hamid et al. (2013), pendidikan ibu rumah tangga terkait dengan pengetahuan dan sikapnya terhadap pemenuhan kebutuhan pangan dan gizi keluarga. Ibu rumah tangga dengan tingkat pendidikan yang lebih tinggi diyakini akan memiliki pemahaman yang lebih baik tentang gizi, meningkatkan kesadaran mereka akan perlunya makan makanan yang sehat. Namun berdasarkan kondisi nyata di lokasi penelitian, pendidikan ibu rumah tangga tidak berpengaruh besar terhadap kebiasaan konsumsi makanan. Lebih lanjut Sirait et al., (2021) kualitas konsumsi harus diperhatikan, dan pendidikan gizi, khususnya bagi perempuan, harus ditingkatkan. Karena mayoritas pendidikan ibu rumah tangga di Desa Kandang sebagian besar adalah sekolah dasar, maka dapat dikatakan bahwa kesadaran akan kandungan nilai gizi juga terbatas karena tingkat pendidikan mereka yang rendah. Alhasil, banyak ibu rumah tangga yang tetap mengutamakan kepuasan di atas nutrisi saat membeli makanan.

\section{Pendapatan Rumah Tangga (X2)}

Nilai t-hitung 1,089 lebih kecil dari nilai t-tabel 1,671, dengan nilai signifikan 0,281 lebih besar dari 0,05 , menurut temuan pengujian. Akibatnya, $\mathrm{H} 0$ diterima tetapi Ha ditolak. Hal ini menunjukkan bahwa variabel pendapatan keluarga tidak berpengaruh terhadap kebiasaan konsumsi makanan rumah tangga. Koefisien regresi X2 bernilai positif sebesar $0,3849 \times 10^{-4}$ yang menunjukkan bahwa kenaikan pendapatan 10.000 rupiah, asupan makan akan meningkat 0,3849 gr/kapita/hari. Pendapatan keluarga tidak berpengaruh signifikan terhadap pola konsumsi makanan, karena setiap rumah tangga sadar akan kebutuhan gizi atau gizinya, dan beberapa rumah tangga memprioritaskan sandang dan perumahan untuk alasan tertentu terkait dengan kepuasan dan selera setiap anggota keluarga. Menurut Yasa (2008), hukum Engel menunjukkan bahwa rumah tangga berupah rendah atau berpenghasilan rendah akan menghabiskan sebagian besar uang mereka untuk kebutuhan pokok. Rumah tangga berpenghasilan tinggi, di sisi lain, hanya akan menghabiskan sebagian kecil dari pengeluaran mereka secara keseluruhan untuk kebutuhan dasar. Namun, ada beberapa rumah dengan sumber daya yang terbatas, oleh karena itu mereka mengganti makanan yang lebih murah dengan makanan alternatif yang lebih mahal di pasaran, mengabaikan kualitas nutrisi dan gizi.

\section{Jumlah Anggota Keluarga (X3)}

Nilai t-hitung sebesar -3.544 lebih besar dari nilai t-tabel sebesar 1.671 , dengan nilai signifikansi 0,001 lebih kecil dari 0,05 yang menunjukkan bahwa $\mathrm{HO}$ ditolak dan Ha diterima. Hal ini menunjukkan bahwa jumlah anggota keluarga berpengaruh besar terhadap kebiasaan konsumsi makanan di rumah. Koefisien regresi variabel X3 negatif sebesar -142,236 menunjukkan bahwa setiap tambahan anggota keluarga mengurangi asupan makanan rumah tangga sebesar 142,236 $\mathrm{g} / \mathrm{kapita} / \mathrm{hari}$. Dari hasil penelitian diketahui bahwa semakin banyak jumlah anggota rumah tangga maka semakin sedikit jumlah makanan yang dikonsumsi. Jika dibandingkan dengan pendapat Suyastri (2008) yang berpendapat bahwa semakin besar jumlah anggota rumah tangga maka semakin besar pula beban yang harus ditanggung rumah tangga tersebut. Fikriman et al. (2020) menunjukkan jumlah anggota keluarga merupakan faktor terpenting yang mempengaruhi pengeluaran pangan rumah tangga miskin. Hal ini tentu bertentangan dengan temuan penelitian ini, yang menunjukkan bahwa ketika sebuah rumah tangga menambah anggota baru, jika pendapatan yang dihasilkan tidak cukup untuk meningkatkan pengeluaran makanan, rumah tangga tersebut akan mengurangi konsumsi untuk mengimbangi jumlah makanan yang dikonsumsi. Hal ini disebabkan oleh kenyataan bahwa rumah tangga akan mempertimbangkan bagaimana memenuhi kebutuhan sehari- 
hari mereka dengan membelanjakan pengeluaran konsumsi makanan berdasarkan pendapatan mereka saat ini. Menurut Hamid et al. (2013), ada dua cara bagi keluarga untuk mengatasi hal ini, yaitu meningkatkan pendapatan rumah tangga atau mengurangi pengeluaran makanan dengan memilih jenis makanan yang lebih murah dan kurang beragam, karena rumah dengan jumlah anggota yang tinggi membutuhkan makanan yang layak secara umum. banyak.

\section{Usia Ibu Rumah Tangga (X4)}

Nilai thitung sebesar 1,339 lebih kecil dari nilai t tabel sebesar 1,671 dengan nilai signifikan sebesar 0,186 yang lebih besar dari 0,05 yang menunjukkan bahwa $\mathrm{H} 0$ diterima dan Ha ditolak. Hal ini menunjukkan bahwa variasi usia ibu rumah tangga tidak memiliki dampak yang besar terhadap tren konsumsi pangan rumah tangga. Nilai positif dari variabel regresi X4 menunjukkan bahwa untuk setiap kenaikan satu tahun usia ibu rumah tangga, konsumsi makanan keluarga meningkat sebesar $7,017 \mathrm{~g} / \mathrm{kapita} / \mathrm{hari}$. Karena makanan yang dikonsumsi menekankan sesuai dengan pendapatan rumah tangga, selera masing-masing anggota keluarga dari berbagai usia, kebiasaan, dan budaya konsumsi, usia ibu rumah tangga tidak berpengaruh terhadap pola konsumsi makanan dalam penelitian ini. Usia ibu rumah tangga mempengaruhi tingkat keahliannya; ibu rumah tangga yang lebih tua biasanya lebih berpengalaman dalam memilih jenis makanan. Hal ini sejalan dengan pendapat (Sumarwan, 2017) bahwa usia ibu rumah tangga yang berbeda akan memakan masakan yang berbeda pula. Preferensi yang berbeda akan muncul sebagai akibat dari perbedaan usia.

\section{KESIMPULAN DAN SARAN}

Berdasarkan temuan kajian pola konsumsi pangan rumah tangga di Desa Kandang Kecamatan Tabir Kabupaten Merangin dapat disimpulkan bahwa pola konsumsi pangan berdasarkan aspek kuantitas pada Tingkat Kecukupan Energi (TKE) masih didominasi kategori defisit, yaitu $70 \%$ dengan rata-rata konsumsi 1000 sampai $1300 \mathrm{kkal} / \mathrm{kapita} / \mathrm{hari}$ dari angka kecukupan gizi anjuran $2.150 \mathrm{kkal} / \mathrm{kapita} / \mathrm{hari}$ dari angka kecukupan gizi yang dianjurkan Sementara itu, kelompok defisit terus mendominasi Tingkat Kecukupan Protein (TKP) terhitung 70\% dari total dengan konsumsi ratarata 19 hingga $38 \mathrm{~g} / \mathrm{kapita} / \mathrm{hari}$ dari tingkat kecukupan gizi yang diperlukan $57 \mathrm{~g} / \mathrm{kapita} / \mathrm{hari}$. Nilai Pola Pangan yang Diharapkan (PPH) untuk pola konsumsi pangan berdasarkan faktor mutu adalah 83,2. Hasil ini jauh dari target PPH nasional 100. Kelompok makanan padi-padian mendominasi pola asupan makanan berdasarkan berat badan, sedangkan sayuran dan buah-buahan memiliki peringkat kelompok makanan tertinggi. Berdasarkan hasil analisis regresi linier berganda, jumlah anggota keluarga merupakan satu-satunya faktor yang berpengaruh signifikan terhadap pola konsumsi pangan, sedangkan faktor lain seperti pendidikan ibu rumah tangga, pendapatan rumah tangga, dan usia ibu rumah tangga tidak berpengaruh. Berdasarkan temuan penelitian, peneliti diharapkan dapat memberikan rekomendasi kepada pemerintah kabupaten yang berperan penting dalam menentukan ketahanan pangan, untuk mengevaluasi dan memantau tidak hanya tingkat kecukupan pangan tetapi juga status gizi penduduk di tingkat rumah tangga. Serta memberikan sosialisasi dan bimbingan tentang perlunya pola makan yang beragam untuk pola makan yang sehat. Pemerintah kabupaten tidak hanya harus meningkatkan layanan dan menawarkan informasi ke kantor desa, tetapi juga pemerintah desa, sehingga calon sarjana dapat mengekstrak informasi atau profil desa dengan lebih mudah. Masyarakat desa harus meningkatkan asupan kalori dari umbi-umbian dan kacangkacangan, serta asupan protein dari umbi-umbian dan buah/biji berminyak. Faktor-faktor lain yang tidak penulis masukkan dalam penelitian ini perlu ditambahkan oleh peneliti selanjutnya.

\section{REFERENSI}

Aemana, U., Limi, M., Zani, M., \& Mariani, M. (2020). Analisis Pengeluaran dan Pola Konsumsi Pangan Rumah Tangga Petani Cengkeh di Kecamatan Lasusua. Buletin Penelitian Sosial Ekonomi Pertanian Fakultas Pertanian Universitas Haluoleo, 21(2), 85 -. doi:http://dx.doi.org/10.33772/bpsosek.v21i2.9493

Ansori, M. (2021). Analisis Pola Konsumsi Pangan Penduduk Kabupaten Lebak. Jurnal Gizi Kerja Dan Produktivitas, 2(2), 38. https://doi.org/10.52742/jgkp.v2i2.12842

Argandi, S., Trimo, L., \& Noor, T. I. (2019). Faktor - Faktor Yang Mempengaruhi Pola Pangan Harapan (PPH) Di Kabupaten Bandung. Jurnal IImiah Mahasiswa AGROINFO GALUH, 6(1), 132. https://doi.org/10.25157/jimag.v6i1.1506

Badan Ketahanan Pangan Kementerian Pertanian. (2015). Panduan Penghitungan Pola Pangan Harapan (PPH). Badan Ketahanan Pangan Kementerian Pertanian. http://bkp.pertanian.go.id/storage/app/media/Evalap/BUKU PEDOMAN PENYUSUNAN 


\author{
PPH.pdf \\ Badan Ketahanan Pangan Kementerian Pertanian. (2018). Direktori Perkembangan Konsumsi \\ Pangan. \\ BPS. (2020). Pola Pangan Harapan (PPH Ketersediaan). Badan Pusat Statistik RI. \\ https://sirusa.bps.go.id/sirusa/
}

Fikriman, F., Budiman, F. A., \& Afrianto, E. (2020). Faktor Sosial Ekonomi yang Mempengaruhi Pengeluaran Pangan Rumah Tangga Miskin di Kecamatan Bangko Kabupaten Merangin. Jurnal Agri Sains, 4(2)(149-161).

Hamid, Y., Setiawan, B., \& Suhartini, S. (2013). Analisis Pola Konsumsi Pangan Rumah Tangga (Studi Kasus di Kecamatan Tarakan Barat Kota Tarakan Provinsi Kalimantan Timur). AGRISE, 8(3).

Nurafif, Huda, A., \& Kusuma, H. (2015). Aplikasi Asuhan Keperawatan Berdasarkan Diagnosa Medis dan NANDA NIC-NOC. Media Action.

Peraturan Menteri Kesehatan Republik Indonesia Nomor 75 Tahun 2013 Tentang Angka Kecukupan Gizi Yang Dianjurkan Bagi Bangsa Indonesia, (2013).

Sirait, B. A., Manurung, A. I., Samosir, O. M., \& Sabrina, R. (2021). Pemantauan Pola Pangan Harapan (PPH) Masyarakat Tingkat Kecamatan Di Kota Medan. Wahana Inovasi, 10(1), 4753. https://jurnal.uisu.ac.id/index.php/wahana/article/view/4285

Sugiyono. (2015). Metode Penelitian Kuantitatif dan Kualitatif $R$ \& D. Alfabeta.

Sumarwan, U. (2017). Perilaku Konsumen: Teori dan Penerapannya dalam Pemasaran (R. Sikumbang (ed.); Edisi Kedua). Ghalia Indonesia.

Supariasa, I. D. N., Bakri, B., \& Fajar, I. (2013). Penilaian Status Gizi (Edisi 2). EGC.

Suyastri. (2008). Diversifikasi Konsumsi Pangan Pokok Berbasis Potensi Lokal dalam Mewujudkan Ketahanan Pangan Rumah Tangga di Kecamatan Semin Kabupaten Gunung Kidul. Jurnal Ekonomi Pembangunan, 13(1), 51-60.

Yasa, I. G. W. M. (2008). Penanggulangan Kemiskinan Berbasis Partisipasi Masyarakat di Provinsi Bali. Jurnal Ekonomi dan Sosial Input. 